\title{
PENGARUH TERAPI BEKAM TERHADAP TEKANAN DARAH PENDERITA HIPERTENSI
}

\author{
Tumiur Sormin* \\ *Jurusan Keperawatan Poltekkes Tanjungkarang
}

\begin{abstract}
Penyakit hipertensi masih merupakan tantangan besar di Indonesia dengan prevalensi yang tinggi. Hasil wawancara kepada penderita hipertensi yang sedang di terapi, 4 orang $(60,66 \%)$ dari 6 orang pasien mengatakan belum tahu tentang terapi bekam yang disertai masage, teknik relaksasi dan belum tau prosedurnya. Jenis penelitian ini adalah eksperimen semu (quasi experiment) dengan menggunakan pendekatan pre-post test design. Populasi penelitian ini adalah seluruh penderita hipertensi tanpa komplikasi dan terdaftar sebagai pengunjung terapi bekam di Klinik Master Bekam Way Halim Bandar Lampung sebanyak 48 orang dan sampel penelitian sebanyak 40 orang. Teknik pengambilan sampel dengan accidental sampling. Uji statistik yang digunakan adalah Uji T-dependen untuk mengetahui ada tidaknya perbedaan tekanan darah sebelum dan sesudah perlakuan/intervensi (terapi bekam). Hasil penelitian diperoleh bahwa responden terbanyak adalah diatas 35 tahun yakni 30 orang (75,00\%), terbanyak laki-laki sebanyak 25 orang $(62,50 \%)$,terbanyak berpendidikan dibawah perguruan tinggi sebanyak 26 orang $(65,00 \%)$, dan terbanyak bekerja sebagai wiraswasta yakni 21 orang $(52,50 \%)$. Sebelum dilakukan terapi bekam, rata-rata tekanan darah sistolik adalah $152,50 \mathrm{mmHg}$ dan rata-rata tekanan diastolik $85,25 \mathrm{mmHg}$. Sesudah terapi bekam diperoleh hasil bahwa rata-rata tekanan darah sistolik adalah $134,25 \mathrm{mmHg}$ dan rata-rata tekanan diastolik $80 \mathrm{mmHg}$. Berdasarkan uji statistik diperoleh hasil $p$-value sebesar 0,000 , artinya terdapat perbedaan tekanan darah sebelum dan setelah terapi bekam.
\end{abstract}

\section{Kata Kunci: Terapi Bekam, Tekanan darah, Hipertensi}

\section{LATAR BELAKANG}

Penyakit hipertensi, stroke, jantung koroner, dan diabetes, sekarang ini masih menjadi penyakit pembunuh nomor satu di Indonesia. Belakangan ini, penyakit tersebut tidak hanya menyerang orang lanjut usia lanjut (lansia) karena faktor degeneratif, tetapi juga usia produktif (Shadine, 2010). Sampai saat ini, hipertensi masih merupakan tantangan besar di Indonesia dengan prevalensi yang tinggi, yaitu sebesar 25,8\% (Riskesdas, 2013).

Menurut Kepala Dinas Kesehatan Provinsi Lampung, perkembangan penyakit hipertensi di Lampung telah menduduki peringkat ke-3 dari 10 penyakit terbanyak pada pasien rawat jalan di Puskesmas.

Prevalensi kasus hipertensi primer di Provinsi Lampung mengalami peningkatan dari tahun ke tahun, sehingga pada tahun 2015 menduduki peringkat ketiga terbesar dari 10 penyakit besar lainnya pada pasien rawat jalan di
Puskesmas. Prevalensi kasus hipertensi lain di Provinsi Lampung tahun 2015 mengalami peningkatan bila dibandingkan prevalensi tahun 2014 sebesar 0,76\%, diantaranya, $12,1 \%$ mengalami stroke (Dinkes Prov Lampung, 2015).

Hasil pre-survey peneliti ke klinik Bekam di Bandar Lampung pada Mei 2017, diketahui bahwa rata-rata kunjungan terapi bekam klien hipertensi adalah 100130 orang per-hari. Ada sebanyak 48 orang klien hipertensi tanpa komplikasi. yang terdaftar melakukan terapi bekam di klinik tersebut. Hasil wawancara kepada klien hipertensi yang sedang terapi, diketahui bahwa 4 orang $(60,66 \%)$ dari 6 orang pasien mengatakan belum pernah tahu tentang terapi bekam disertai masage dan teknik relaksasi. Klien juga mengatakan belum tau prosedur dan manfaat akhir terapi bekamnya.

Berdasarkan uraian diatas, pada penelitian ini adanya keinginan menerapkan terapi bekam kepada penderita hipertensi dengan prosedur yang sebenarnya. Melalui penelitian ini, ingin 
mengetahui pengaruh terapi bekam terhadap tekanan darah pada penderita hipertensi.

\section{METODE}

Rancangan penelitian yang digunakan adalah eksperimen semu (quasi experiment) yaitu dengan menggunakan pendekatan pre-post test only design. Populasi penelitian ini adalah seluruh penderita hipertensi tanpa komplikasi dan sebanyak 48 orang dan sampel penelitian sebanyak 40 orang. Teknik pengambilan sampel dengan accidental sampling.

Sampel penelitian akan mengalami perlakuan (eksperimen) berupa terapi bekam. Kepada sampel penelitian yang sama akan dilakukan pengukuran tekanan darah sebanyak dua kali, yakni sebelum dilakukan terapi bekam (pre-test) dan sesudah dilakukan terapi bekam (posttest). Uji statistik yang digunakan adalah Uji t-dependen untuk mengetahui ada tidaknya perbedaan tekanan darah sebelum dan sesudah perlakuan/intervensi (terapi bekam).

\section{HASIL}

\section{Karakteristik Responden}

Tabel 1: Distribusi Responden Menurut Umur, Jenis Kelamin, Pendidikan, dan Pekerjaan

\begin{tabular}{lcc}
\hline Variabel & $\mathrm{f}$ & $\%$ \\
\hline Umur: & & \\
$<35$ tahun & 10 & 25,0 \\
$\geq 35$ tahun & 30 & 75,0 \\
\hline Jenis Kelamin: & & \\
Laki-laki & 25 & 62,5 \\
Perempuan & 15 & 37,5 \\
\hline Pendidikan: & & \\
SMU ke bawah & 26 & 65,0 \\
PT & 14 & 35,0 \\
\hline Pekerjaan: & & \\
Tidak bekerja & 9 & 22,5 \\
PNS & 10 & 25,0 \\
Swasta & 21 & 52,5 \\
\hline
\end{tabular}

Tabel di atas menunjukkan bahwa responden terbanyak berumur $\geq 35$ tahun, (75\%), jenis kelamin terbanyak adalah laki-laki $(62,5 \%)$, pendidikan terbanyak adalah SMA ke bawah (65\%) dan pekerjaan terbanyak adalah pekerja swasta $(52,5 \%)$.

\section{Analisis Univariat}

Tabel 2: Distribusi Responden Menurut Tekanan Darah Sistol dan Diastol

\begin{tabular}{lcc}
\hline \multicolumn{1}{c}{ TD Sistol } & f & $\%$ \\
\hline Sebelum bekam: & & \\
$<130 \mathrm{mmHg}$ & 0 & 0.0 \\
$\geq 130 \mathrm{mmHg}$ & 40 & 100,0 \\
\hline Sesudah bekam: & & \\
$<130 \mathrm{mmHg}$ & 10 & 25,0 \\
$\geq 130 \mathrm{mmHg}$ & 30 & 75,0 \\
\hline TD diastole sebelum & & \\
bekam: & & \\
$<90 \mathrm{mmHg}$ & 6 & 15,0 \\
$\geq 90 \mathrm{mmHg}$ & 34 & 85,0 \\
\hline TD diastole sesudah & & \\
bekam: & & \\
$<90 \mathrm{mmHg}$ & 25 & 62.5 \\
$\geq 90 \mathrm{mmHg}$ & 15 & 37,5 \\
\hline
\end{tabular}

Tabel di atas menunjukkan bahwa sebelum terapi bekam $100 \%$ memiliki tekanan darah sistole $\geq 130 \mathrm{mmHg}$ dan tekanan darah diastole responden terbanyak 34 orang (85\%) dengan tekanan $\geq 90 \mathrm{mmHg}$. Sesudah terapi bekam, 30 orang $(75 \%)$ bertekanan darah sistole $\geq$ $130 \mathrm{mmHg}$ dan 25 orang responden $(62,5 \%)$ dengan tekanan darah diastole < $90 \mathrm{mmHg}$.

Tabel 3: Distribusi Tekanan Darah Sistol dan Diastol Sebelum dan Sesudah Bekam Kelompok Eksperimen

\begin{tabular}{|c|c|c|c|c|}
\hline \multirow{2}{*}{ Tekanan Darah } & \multirow{2}{*}{ Mean } & \multirow{2}{*}{ Med } & \multicolumn{2}{|c|}{ Range } \\
\hline & & & Min & Maks \\
\hline Sistole Sebelum & 152,50 & 150 & 140 & 180 \\
\hline Sistole Sesudah & 134,25 & 130 & 120 & 160 \\
\hline Diastole Sebelum & 89,25 & 90 & 90 & 110 \\
\hline Diastole Sesudah & 82,75 & 80 & 70 & 70 \\
\hline
\end{tabular}


tekanan darah sistol adalah 152,50 $\mathrm{mmHg}$, median $150 \mathrm{mmHg}$, terendah $140 \mathrm{mmHg}$ dan tertinggi $180 \mathrm{mmHg}$. Setelah terapi bekam rata-rata $134,25 \mathrm{mmHg}$, median $130 \mathrm{mmHg}$, terendah $120 \mathrm{mmHg}$ dan tertinggi $160 \mathrm{mmHg}$. Sedangkan tekanan darah diastol sebelum terapi menunjukkan nilai mean adalah $89,25 \mathrm{mmHg}$, median 90 $\mathrm{mmHg}$, terendah $90 \mathrm{mmHg}$ dan tertinggi $110 \mathrm{mmHg}$. Setelah terapi menunjukkan nilai mean adalah $82,75 \mathrm{mmHg}$, median adalah $80 \mathrm{mmHg}$, terendah $70 \mathrm{mmHg}$ dan tertinggi $70 \mathrm{mmHg}$.

\section{Analisis Bivariat}

Tabel 4: Distribusi Analisis Uji Beda Mean Tekanan Darah Sistol Sebelum dan Sesudah Terapi Bekam

\begin{tabular}{cccccc}
\hline $\begin{array}{c}\text { Tekanan Darah } \\
\text { Sistol }\end{array}$ & Mean & SD & SE & $\begin{array}{c}p \\
\text { value }\end{array}$ & $\mathrm{n}$ \\
\hline $\begin{array}{l}\text { Sebelum bekam } \\
\text { Sesudah bekam }\end{array}$ & 152,50 & 12,14 & 1,92 & 0,000 & 40 \\
\hline
\end{tabular}

Rata-rata tekanan darah sistol pada pengukuran pertama adalah 152,50 dengan standar deviasi 12,14. Pada pengukuran kedua didapat rata-rata tekanan darah sistol 134,25 dengan ratarata standar deviasi 11,95 . Terlihat nilai mean perbedaan antara pengukuran pertama dan kedua adalah 18,25 dengan standar deviasi 5,94. Hasil uji statistik didapatkan $p$ value 0,000 , maka dapat disimpulkan ada perbedaan yang signifikan antara tekanan darah sistole pengukuran sebelum dan sesudah terapi bekam.

Tabel 5: Distribusi Analisis Uji Beda Mean Tekanan Darah Diastol Sebelum dan Sesudah Terapi Bekam

\begin{tabular}{llllll}
\hline $\begin{array}{c}\text { Tekanan Darah } \\
\text { Diastol }\end{array}$ & Mean & SD & SE & $\begin{array}{c}p \\
\text { value }\end{array}$ & $\mathrm{n}$ \\
\hline Pengukuran I & 89,25 & 8,28 & 1,31 & 0,000 & 40 \\
Pengukuran II & 82,75 & 6,40 & 1,01 & & \\
\hline
\end{tabular}

Rata-rata tekanan darah diastole pada pengukuran pertama adalah 89,25 dengan standar deviasi 8,28. Pada pengukuran kedua didapat rata-rata tekanan darah diastole 82,75 dengan ratarata standar deviasi 6,40 . Terlihat nilai mean perbedaan antara pengukuran pertama dan kedua adalah 6,50 dengan standar deviasi 5,79. Hasil uji statistik didapatkan $\mathrm{p}$ value 0,000 , maka dapat disimpulkan ada perbedaan yang signifikan antara tekanan darah diastol sebelum dan sesudah terapi bekam.

\section{PEMBAHASAN}

Hasil penelitian didapat responden terbanyak adalah berumur $\geq 35$ tahun yakni sebanyak 30 orang (75\%), terbanyak adalah laki-laki sebanyak 25 orang $(62,5 \%)$, terbanyak dengan latar belakang pendidikan dibawah perguruan tinggi, yakni sebanyak 26 orang $(65 \%)$ dan bekerja sebagai pekerja swasta, yaitu sebanyak 21 orang $(52,5 \%)$. Jika dilihat dari hasil yang digambarkan oleh Kemenkes RI pada tahun 2007 dan tahun 2013, bahwa prevalensi hipertensi berdasarkan jenis kelamin menunjukkan angka yang terbalik dimana yang digambarkan bahwa hipertensi pada perempuan lebih tinggi dibandingkan dengan hipertensi pada laki-laki.

Menurut Direktorat Pengendalian Penyakit Tidak Menular (2006) bahwa semakin bertambahnya umur, risiko terkena hipertensi menjadi lebih besar, sehingga dikalangan usia lanjut hipertensi menjadi cukup tinggi. Disebutkan pula bahwa di usia dewasa muda, pria lebih banyak menderita hipertensi dibandingkan wanita. Hasil penelitian ini menunjukkan bahwa responden terbanyak adalah berumur $\geq 35$ tahun, termasuk dalam kategori dewasa muda, sehingga hal ini sejalan dengan pendapat yang dikemukakan Direktorat Pengendalian Penyakit Tidak Menular (2006) bahwa hipertensi di usia ini lebih banyak terjadi pada laki-laki dan dengan semakin bertambahnya usia ini, sangat memungkinkan akan terjadi peningkatan prevalensi hipertensi. 
Menurut Hananto, 2008, umumnya faktor yang menyebabkan hipertensi usia muda berkaitan dengan gaya hidup. Selain obesitas, faktor lainnya adalah stres. Stres merupakan masalah di semua kelompok umur, tidak terkecuali orang muda zaman sekarang. Ketika seseorang mengalami stres, tubuh akan merespon dengan perubahan-perubahan fisiologis, kenaikan tekanan darah. Berdasarkan hasil penelitian Sophi Damayanti, dkk (2012) tentang Profil Penggunaan Terapi Bekam di Kabupaten/Kota Bandung Ditinjau dari Aspek Demografi, Riwayat Penyakit, dan Profil Hematologi, diperoleh hasil bahwa terapi bekam banyak digunakan oleh masyarakat pada rentang 20-39 tahun $(70,63 \%)$ dan usia ini adalah usia dewasa muda. Berdasarkan beberapa uraian teori dan hasil penelitian yang diuraikan diatas ini, dapat disimpulkan bahwa penderita hipertensi pada kelompok usia muda, baik wanita maupun laki-laki, cukup tinggi angka pencarian pengobatan terapi bekam.

Berdasarkan hasil penelitian hasil rata-rata perubahan tekanan darah sistole sebelum dan sesudah terapi bekam adalah sebesar 18,25 dengan standar deviasi 5,94. Sedangkan hasil rata-rata perubahan tekanan darah diastole sebelum dan sesudah terapi bekam adalah sebesar 6,50 dengan standar deviasi 5,79. Selanjutnya berdasarkan hasil analisis bivariat diperoleh nilai $p$ value sebelum dan sesudah terapi bekam, pada tekanan darah sistole, maupun tekanan darah diastole, yakni sebesar 0,000 yang berarti terdapat perbedaan bermakna rata-rata tekanan darah sistole dan diastole sebelum dan sesudah terapi bekam. Mean, maximal dan minimal tekanan darah sistole sebelum dilakukan terapi bekam adalah mean 152,50 masuk pada kategori hipertensi sedang.

Terapi bekam yang dilakukan pada titik yang tepat, maka pada kulit (kutis), jaringan bawah kulit (sub kutis), fascia dan ototnya akan terjadi kerusakan dari must cells dan lain-lain, dan akibat kerusakan ini akan dilepaskan beberapa zat seperti serotonin, histamin, bradikinin, slow reacting substance (SRS), serta zat-zat lain yang belum diketahui. Zat-zat ini menyebabkan terjadinya dilatasi kapiler dan arteriol, serta flare reaction pada daerah yang dibekam. Dilatasi kapiler ini menyebabkan terjadinya perbaikan mikrosirkulasi pembuluh darah dan akan timbul efek relaksasi (pelemasan) pembuluh darah, otot-otot yang kaku serta akibat vasodilatasi umum akan menurunkan tekanan darah secara stabil.

Terapi bekam pada penelitian ini, dilakukan dengan metode bekam basah oleh terapis kepada responden. Sebelum dilakukan penyayatan di permukaan kulit, pada bagian yang akan disayat dilakukan masage. Tindakan pengeluaran darah kotor (blood letting) dilakukan dengan cara menyayat dengan lanset steril pada bagian yang dibekam, kemudian darah yang keluar dihisap dengan tabung sampai seluruh darah terhisap seluruhnya dari permukaan kulit yang disayat. Setelah dilakukan bekam, pasien dibantu duduk untuk selanjutnya dilakukan teknik relaksasi lebih kurang 15 menit. Setelah pasien nyaman barulah diperbolehkan berdiri dan berjalan untuk persiapan pulang. Selama proses pembekaman, peneliti melakukan komunikasi terapeutik dengan tujuan terjadi relaksasi dan menghilangkan rasa takut pada pasien. Perubahan rata-rata tekanan darah sistole maupun diastole pada responden tampak secara nyata setelah dilakukan 2 kali pembekaman dengan jarak waktu 2 minggu. Bahkan ada beberapa pasien yang tekanan darahnya telah kembali ke tekanan darah normal.

Jika dilihat hasil penelitian Sangkur, B, dkk (2014) tentang Pengaruh Terapi Bekam Terhadap Tekanan Darah Pasien Hipertensi Esensial di Rumah Bekam Denpasar, bahwa bekam menurunkan tekanan darah pada pasien hipertensi. Penelitian Saryono (2010) tentang Penurunan Kadar Kolesterol Total pada Pasien Hipertensi yang Mendapat Terapi Bekam di Klinik An-Nahl Purwokerto, diperoleh juga hasil bahwa upaya penurunan kadar kolestrol darah dapat dilakukan dengan terapi bekam. 
Hasil penelitian yang diperoleh peneliti, tampaknya sejalan dengan beberapa hasil penelitian yang diuraikan diatas, dimana ada perubahan tekanan darah sebelum dan sesudah pembekaman. Penelitian yang dilakukan beberapa peneliti yang diuraikan diatas, tidak jelas diuraikan tentang masage sebelum dan teknik relaksasi sesudah pembekaman, maupun penerapan komunikasi terapeutik, sehingga kemungkinan tidak diterapkannya tindakan tersebut selama pembekaman. Tindakan bekam yang diteliti oleh peneliti, sebelum pembekaman diawali dengan masage dan setelah pembekaman dilakukan teknik relaksasi. Tindakan masage dan teknik relaksasi tampaknya lebih nyaman dan keadaan ini sangat membantu menyiapkan fisik dan psikologis klien menjalani pembekaman. Oleh karena itu, dengan adanya hasil penelitian yang menunjukkan bahwa adanya perbedaan yang signifikan antara tekanan darah sistole dan diastole sebelum dan sesudah dilakukan terapi bekam, membuktikan bahwa terapi bekam yang diawali dengan masage dan diakhiridengan relaksasi dan disertai komunikasi terapeutik merupakan salah satu terapi yang dapat direncanakan mengatasi masalah penyakit hipertensi.

Beberapa faktor resiko yang menyebabkan hipertensi menurut Direktorat Pengendalian Penyakit Tidak Menular, 2006, termasuk diantaranya adalah gaya hidup modern yang berusaha mengatasi stresnya dengan merokok dan minum alkohol atau kopi. Pengaruh alkohol terhadap kenaikan tekanan darah telah dibuktikan. Alkohol menyebabkan peningkatan kadar kortisol peningkatan volume sel darah merah serta kekentalan darah kadar kortisol, dan peningkatan volume sel darah merah serta kekentalan darah berperan dalam menaikan tekanan darah. Konsumsi garam berlebih dan makanan berkolesterol tinggi, termasuk sebagai faktor resiko terjadinya hipertensi.

Tujuan utama penangan hipertensi adalah menurunkan tekanan darah sehingga kemungkinan terjadinya berbagai komplikasi yang diuraikan diatas tidak terjadi. Mengendalikan berbagai faktor resiko hipertensi adalah merupakan tindakan yang tepat dan sangat dibutuhkan oleh penderita hipertensi untuk menurunkan tekanan darah tingginya menjadi normal kembali. Terapi bekam dilakukan dengan cara menghisap atau menyedot zat toksik yang tidak terekskresikan oleh tubuh melalui permukaan kulit, dimana zat toksik inilah meruapakan salah satu penyebab hipertensi.

\section{KESIMPULAN}

Umur responden terbanyak $\geq 35$ tahun,yaitu 30 orang $(75,00 \%)$, terbanyak responden laki-laki sebanyak 25 orang $(62,50 \%)$, responden terbanyak berpendidikan dibawah perguruan tinggi yaitu 26 orang $(65,00 \%)$, dan responden terbanyak bekerja wiraswasta sebanyak 21 orang $(52,50 \%)$

Sebelum dilakukan terapi bekam, rata-rata tekanan darah sistolik adalah 152,50, kategori hipertensi sedang. nilai maksimal adalah 180 kategori hipertensi berat dan minimal adalah 140 kategori hipertensi ringan. Sesudah terapi bekam, rata-rata tekanan darah sistolik adalah 134, 25 kategori tinggi normal, nilai maksimal adalah 160 kategori hipertensi sedang dan minimal adalah 120 kategori normal. Sebelum dilakukan terapi bekam, rata-rata tekanan darah diastole adalah 85,25 , kategori hipertensi tinggi normal, nilai maksimal adalah 110 kategori hipertensi sedang dan minimal adalah 90 kategori hipertensi ringan. Sesudah dilakukan terapi bekam, rata-rata tekanan darah diastole adalah 80, kategori normal, nilai maksimal adalah 70 kategori normal. Hasil uji statistik didapatkan p-value 0,000 , yang berarti ada perbedaan yang signifikan antara tekanan darah sistole dan diastole pengukuran pertama (sebelum terapi bekam) dan pengukuran kedua (setelah terapi bekam).

Diharapkan supaya institusi pendidikan keperawatan menjadikan terapi bekam sebagai salah satu intervensi 
keperawatan sebagai terapi modalitas untuk mengatasi tekanan darah tinggi. Masage sebelum pembekaman dan teknik relaksasi setelah pembekaman disertai komunikasi terapeutik supaya diterapkan di klinik bekam kepada setiap pasien hipertensi yang datang terapibekam.

\section{DAFTAR PUSTAKA}

Direktorat Pengendalian Penyakit Tidak Menular Direktorat Jenderal PP \& PL, 2006, Pedoman Teknis Penemuan dan Tatalaksana Penyakit Hipertensi, Jakarta: Departemen Kesehatan Republik Indonesia.

Dinkes Propinsi Lampung, 2015.,Profil Kesehatan, Dinkes Propinsi Lampung
Sangkur, B, dkk, 2014. Pengaruh Terapi Bekam Terhadap Tekanan Darah Pasien Hipertensi Esensial Di Rumah Bekam Denpasar

Saryono, 2010. Penurunan Kadar Kolesterol Total pada Pasien Hipertensi yang Mendapat Terapi Bekam di Klinik An-Nahl Purwokerto

Sheldon G. Shep, 2005, Mayo Clinic Hipertensi, Mengatasi Tekanan Darah Tinggi, Jakarta: PT. Intisari Mediatama.

Sophi Damayanti, dkk, 2012. Profil Penggunaan Terapi Bekam di Kabupaten/Kota Bandung Ditinjau dari Aspek Demografi, Riwayat Penyakit, dan Profil Hematologi 